\title{
Pengaruh perbedaan waktu turun hujan terhadap aplikasi herbisida kalium glifosat dalam mengendalikan gulma dominan kelapa sawit
}

\section{Effect of rainfall on application of potassium glyphosate herbicide in controlling dominant oil palm weeds}

Diterima : 23 Februari 2019/Disetujui : 25 Maret 2019 / Dipublikasikan : 31 Maret 2019

CDepartment of Crop Science, Padjadjaran University

\begin{abstract}
The low productivity of oil palm is caused by competition between crop with weeds. Weed control with potassium glyphosate 660 g.L-1 herbicide has been done and is considered effective. Rainfall after herbicide application can be a problem because efficacy can be less effective. This study aims to determine the effect of rainfall on effectivity of potassium glyphosate 660 g.L-1 herbicide in controlling the dominant weeds of oil palm. The study was carried out at the Ciparanje Experimental Greenhouse, Faculty of Agriculture, Padjadjaran University, from February to April 2018. The experimental design used Randomized Block Design, that consisted of 7 treatments and 4 replications. The treatments were the time of rainfall after application of potassium glyphosate 660 g.L-1 herbicide. It consisted of $0,1,2$, 3, and 4 hours after herbicide application, without rainfall, and without herbicide application. The treatment was applied to 6 types of weeds. There were Asystasia intrusa, Imperata cylindrica, Borreria alata, Ageratum conyzoides, Paspalum conjugatum, and Setaria plicata. The experimental results showed that potassium glyphosate 660 g.L-1 was able to control 5 types of weeds. There were I. cylindrica, A. conyzoides, S. plicata (each percentage of damage was $100 \%)$; B. alata (90-100\% damage percentage); P. conjugatum $(51.5$ - $100 \%$ damage percentage); was controlled in rainfall at $2-4$ hours after herbicide application. Potassium glyphosate 660 g.L-1 herbicide controlled I. cylindrica $\quad(79.6 \%$ damage percentage); B. Alata and A. conyzoides (each percentage of damage was 100\%); in rainfall at less than 2 hours after herbicide application.
\end{abstract}

Keyword: Palm oil • Dominant weed · Potasium Glyphosate • Rainfall

\footnotetext{
Dikomunikasikan oleh Koko Tampubolon

Kurniadie, D. · Y. Sumekar · S. Nulkarim

Departemen Agronomi, Fakultas Pertanian, Universitas

Padjadjaran,

Korespondensi: yayan.sumekar@gmail.com
}

Sari. Rendahnya produktivitas kelapa sawit salah satunya disebabkan oleh adanya kompetisi tanaman dengan gulma. Pengendalian gulma dengan herbisida kalium glifosat $660 \mathrm{~g} / \mathrm{L}$ sudah banyak dilakukan dan dinilai efektif. Hambatan yang terjadi yaitu terkadang turun hujan setelah aplikasi herbisida yang menyebabkan efikasi kurang efektif. Penelitian ini bertujuan untuk mengetahui ketahanan herbisida kalium glifosat $660 \mathrm{~g} / \mathrm{L}$ akibat pencucian air hujan dalam mengendalikan gulma dominan pada tanaman kelapa sawit. Penelitian dilaksanakan di Rumah Kaca Fakultas Pertanian Universitas Padjadjaran Jatinangor pada bulan Februari sampai bulan April 2018. Rancangan yang digunakan dalam penelitian ini yaitu Rancangan Acak Kelompok yang terdiri dari 7 perlakuan dan 4 ulangan. Perlakuan yang diberikan adalah waktu turun hujan setelah aplikasi herbisida kalium glifosat 660 $\mathrm{g} / \mathrm{L}$, yang terdiri dari $0,1,2,3$, dan 4 jam setelah aplikasi, tanpa hujan, serta tanpa aplikasi herbisida. Perlakuan diterapkan pada 6 jenis gulma, yaitu Asystasia intrusa, Imperata cylindrica, Borreria alata, Ageratum conyzoides, Paspalum conjugatum dan Setaria plicata. Hasil percobaan menunjukkan bahwa herbisida kalium glifosat 660 $\mathrm{g} / \mathrm{L}$ mampu mengendalikan 5 jenis gulma yaitu $I$. cylindrica, A. conyzoides, S. plicata (persentase kerusakan masing-masing $100 \%) ; B$. alata (persentase kerusakan $90-100 \%$ ); dan $P$. conjugatum (persentase kerusakan 51,5 - 100\%); secara efektif walaupun tercuci air hujan antara 2 - 4 jam setelah aplikasi. Herbisida kalium glifosat $660 \mathrm{~g} / \mathrm{L}$ mampu mengendalikan gulma I. cylindrica (persentase kerusakan 79,6\%); B. alata, dan A. conyzoides (persentase kerusakan masing-masing $100 \%$ ); dengan rentang waktu kurang dari 2 jam setelah aplikasi sebelum tercuci air hujan.

Kata kunci: Kelapa Sawit • Gulma dominan • Kalium glifosat $660 \mathrm{~g} / \mathrm{L}$. Turun hujan 


\section{Pendahuluan}

Tanaman kelapa sawit merupakan tanaman perkebunan yang cukup luas dibudidayakan di Indonesia. Luas area perkebunan kelapa sawit mencapai 10.754.801 ha pada tahun 2014 dari awalnya hanya 294.560 ha (1980), yang terdiri dari perkebunan rakyat, perkebunan negara, dan perkebunan swasta (Astuti $d k k$., 2014). Hal ini menunjukkan bahwa dalam beberapa tahun Indonesia mengalami perluasan perkebunan kelapa sawit yang signifikan, dan diperkirakan akan terus bertambah setiap tahunnya, dan menjadikan Indonesia sebagai salah satu negara penghasil minyak nabati dari kelapa sawit terbesar di dunia. Produktivitas kelapa sawit belum bisa dikatakan baik jika ditinjau dari perbandingan antara hasil panen dengan luas area perkebunan. Pokja Sawit (2008) menyatakan bahwa produktivitas perkebunan sawit rakyat hanya menghasilkan 16 ton Tandan Buah Segar (TBS) per ha, padahal potensinya bisa mencapai 30 ton TBS/ha. Hal itu membuktikan bahwa produktivitas perkebunan kelapa sawit hanya mencapai $\pm 53,3 \%$ dari potensinya, sehingga dapat disimpulkan produktivitasnya masih rendah. Menurut Risza (1994), rendahnya produktivitas perkebunan kelapa sawit di Indonesia disebabkan oleh beberapa faktor, salah satunya adalah akibat adanya kompetisi tanaman dengan gulma.

Gulma pada perkebunan kelapa sawit bersifat sangat kompetitif sehingga mengakibatkan penurunan kualitas dan kuantitas hasil tanaman. Terdapat beberapa jenis gulma yang hampir selalu ada atau bersifat dominan di perkebunan kelapa sawit, seperti gulma Boreria alata, Ageratum conyzoides, Asystasia intrusa, Imperata cylindrica, Paspalum conjugatum, Staria plicata, Emilia sonchifolia, dan Erigeron sumantresis (Purwasih dkk., 2013). Gulma-gulma tersebut biasanya tumbuh dengan cepat diantara tanaman kelapa sawit, karena memiliki ruang tumbuh yang luas, sehingga dibutuhkan pengendalian secara cepat dan efektif. Menurut Sembodo (2010), pengendalian gulma yang paling efektif untuk gulma pada tanaman sawit yaitu pengendalian secara kimiawi dengan menggunakan herbisida. Selain dapat mempercepat pekerjaan, pengendalian tersebut lebih hemat biaya dari segi kebutuhan tenaga kerja.

Pengendalian gulma meggunakan herbisida diperlukan pengetahuan dasar tentang cara pemakaiannya, ketepatan dosis, dan waktu aplikasi (Girsang, 2005). Ketepatan waktu aplikasi herbisida merupakan salah satu hal yang sangat penting untuk diperhatikan dalam pengendalian gulma. Kondisi cuaca yang mengindikasikan akan turun hujan sebaiknya dihindari, karena akan terjadi pencucian yang mengurangi efektivitas herbisida (Reddy dan Singh, 1992). Oleh karena itu, diperlukan herbisida yang tetap efektif mengendalikan gulma meskipun turun hujan.

Herbisida berbahan aktif glifosat adalah salah satu yang banyak digunakan untuk mengendalikan gulma pada perkebunan kelapa sawit. Herbisida ini bersifat sistemik dan nonselektif yang dapat mengendalikan berbagai jenis gulma baik gulma semusim, setahun, tahunan, golongan rumput, golongan teki, ataupun golongan daun lebar (Supriadi $d k k$., 2012). Herbisida glifosat bekerja dengan cara mengganggu fisiologis tumbuhan melalui proses absorbsi oleh daun dan ditranslokasikan pada seluruh bagian secara sistemik ke jaringan hidup dan pembuluh phloem menuju ke jaringan meristem (Sriyani, 2010).

Herbisida glifosat harus bebas hujan 6-8 jam setelah aplikasi (Reddy dan Singh, 1992). Bahan tambahan berupa surfactant atau adjuvant dalam formulasi herbisida dapat meningkatkan daya kerja herbisida. terutama untuk meningkatkan kemampuan dispersi/ mengemulsi, menyerap, menyebarkan dan menempel (Miller dan Westra, 1998). Herbisida kalium glifosat 660 $\mathrm{g} / \mathrm{L}$ memiliki perbedaan formulasi herbisida yang akan menentukan daya kerja dan selektivitasnya. Keberhasilan pengendalian gulma dapat diketahui dengan dilakukan pengujian untuk mengetahui pengaruh pemberian hujan terhadap aplikasi herbisida kalium glifosat $660 \mathrm{~g} / \mathrm{L}$ dalam mengendalikan gulma dominan kelapa sawit, sehingga akan diketahui berapa lama herbisida efektif mengendalikan gulma sebelum tercuci air hujan.

\section{Bahan dan Metode}

Percobaan ini dilakukan pada bulan Februari April 2018, di Rumah Kaca Fakultas Pertanian Universitas Padjadjaran, Desa Cileles, Kecamatan Jatinangor, Sumedang pada ketinggian $725 \mathrm{~m}$ dpl. Alat yang digunakan untuk penelitian ini adalah sprayer knapsack semi automatis, sprinkler, pot, gelas ukur, pipet, gunting, cangkul, oven, pot, 
label, timbangan analitik, oven, dan penakar curah hujan. Bahan yang digunakan adalah gulma daun lebar (Borreria alata, Ageratum conyzoides, Asystasia intrusa) dan gulma daun sempit (Imperata cylindrica, Paspalum conjugatum, Staria plicata) dan herbisida dengan bahan aktif kalium glifosat 660 g/L. Rancangan percobaan yang digunakan adalah Rancangan Acak Kelompok (RAK), yang terdiri dari 7 perlakuan dan 4 ulangan. Perlakuan yang diberikan adalah pemberian herbisida kalium glifosat $660 \mathrm{~g} / \mathrm{L}$ dilanjutkan pemberian hujan dengan jeda waktu 0, 1, 2, 3, dan 4 jam setelah aplikasi; aplikasi herbisida tanpa diberikan hujan; serta tanpa aplikasi herbisida. Pemberian hujan pada gulma dilakukan setelah aplikasi herbisida kalium glifosat $660 \mathrm{~g} / \mathrm{L}$ sesuai jeda waktu aplikasi. Setiap perlakuan disusun di area yang telah ditentukan dan diacak dalam setiap ulangannya. Pemberian hujan dilakukan dengan menggunakan sprinkler secara merata. Dosis bahan aktif herbisida kalium glifosat $660 \mathrm{~g} / \mathrm{L}$ yang digunakan adalah $726 \mathrm{~g} / \mathrm{ha}$.

Pengamatan dilakukan terhadap :

1. Gejala keracunan gulma :

Gejala keracunan gulma diamati secara visual (menguning, berwarna coklat, mengering, dan mati) dan dilakukan skoring pada 1, 2, dan 3 minggu setelah dihujani untuk menggambarkan kecepatan gulma teracuni. Skoring keracunan gulma dijelaskan pada Tabel 1.

2. Bobot kering gulma :

Pengamatan bobot kering gulma dilakukan dengan memanen gulma segar dan dipisahkan sesuai perlakuan pada 3 minggu setelah aplikasi (MSA). Setelah itu dikeringkan dalam oven dengan suhu $80^{\circ} \mathrm{C}$ selama 48 jam untuk memperoleh bobot kering konstan. Bagian terakhir adalah penimbangan bobot kering gulma dengan menggunakan timbangan analitik. Hasil diuji statistik dengan uji lanjut Duncan pada taraf $5 \%$.

3. Persentase kerusakan :

Persentase kerusakan gulma merupakan nilai yang menunjukkan seberapa besar kemampuan herbisida dalam mematikan gulma. Nilai persen kerusakan dapat diperoleh dengan cara membandingkan nilai bobot kering perlakuan herbisida dengan kontrol menggunakan persamaan berikut:

Persentase Kerusakan $(\%)=(1-$ $\left.\left(\frac{\text { Bobot kering perlakuan }}{\text { Bobot kering kontrol }}\right)\right) x 100 \%$
Tabel 1 Skoring Gejala Keracunan Gulma.

\begin{tabular}{|c|c|c|}
\hline No & Nilai & Keterangan \\
\hline 1 & 0 & $\begin{array}{l}\text { Tidak ada keracunan, } 0-5 \% \text { bentuk } \\
\text { dan atau warna daun dan atau } \\
\text { pertumbuhan gulma tidak normal. }\end{array}$ \\
\hline 2 & 1 & $\begin{array}{l}\text { Keracunan ringan, }>5-20 \% \text { bentuk } \\
\text { dan atau warna daun dan atau } \\
\text { pertumbuhan gulma tidak normal. }\end{array}$ \\
\hline 3 & 2 & $\begin{array}{l}\text { Keracunan sedang, }>20-50 \% \text { bentuk } \\
\text { dan atau warna daun dan atau } \\
\text { pertumbuhan gulma tidak normal. }\end{array}$ \\
\hline 4 & 3 & $\begin{array}{l}\text { Keracunan berat, }>50-75 \% \text { bentuk } \\
\text { dan atau warna daun dan atau } \\
\text { pertumbuhan gulma tidak normal. }\end{array}$ \\
\hline 5 & 4 & $\begin{array}{l}\text { Keracunan sangat berat, }>75 \% \\
\text { bentuk dan atau warna daun dan } \\
\text { atau pertumbuhan gulma tidak } \\
\text { normal dan mati. }\end{array}$ \\
\hline
\end{tabular}

\section{Hasil dan Pembahasan}

Hasil skoring gulma Asystasia intrusa. Gulma A. intrusa memperlihatkan tingkat keracunan yang lambat dibandingkan dengan gulma lainnya. Berikut merupakan hasil pengamatan nilai skoring gulma $A$. intrusa (Gambar 1.). Pada Gambar 1 terlihat bahwa gulma Asystasia intrusa mengalami gejala keracunan yang tidak terlalu tinggi (perlakuan A-E) jika dibandingkan dengan perlakuan $F$. Bahkan yang paling tinggi diantara perlakuan yang diberikan perlakuan hujan (perlakuan A-E) adalah perlakuan D yang hanya mencapai $40 \%$ pada 3 minggu setelah aplikasi (MSA). Perlakuan A, B, dan C menunjukkan nilai keracunan yang paling rendah sampai 3 MSA sebesar 12\%, sedangkan perlakuan E menunjukkan kenaikan nilai keracunan dari minggu kedua ke minggu ketiga walaupun hanya bertambah $15 \%$. Secara umum (tanpa ada hujan) herbisida kalium glifosat $660 \mathrm{~g} / \mathrm{L}$ mampu mengendalikan gulma Asystasia intrusa. Selain itu diketahui bahwa semakin lama jeda waktu turun hujan setelah aplikasi maka semakin baik tingkat pengendalian gulmanya. Hal ini diduga herbisida kalium glifosat $660 \mathrm{~g} / \mathrm{L}$ membutuhkan waktu lebih banyak untuk meresap ke dalam jaringan gulma Asystasia intrusa sebelum tercuci oleh air hujan. Menurut Priambodo (2017) herbisida kalium glifosat yang dihujani $0-4$ jam setelah aplikasi tidak efektif mengendalikan pertumbuhan gulma Asystasia intrusa. 
Hasil skoring gulma Imperata cylindrica. Herbisida kalium glifosat $660 \mathrm{~g} / \mathrm{L}$ menunjukkan hasil yang lebih baik dalam mengendalikan gulma I. cylindrica dibandingkan dengan gulma A. intrusa. Gambar 2 menunjukkan tingkat keracunan pada 6 perlakuan dalam 3 MSA pengamatan. Herbisida kalium glifosat mampu menekan pertumbuhan gulma I. cylindrica de- ngan cepat. Perlakuan F menunjukkan hasil terbaik pada pengamatan 2 MSA dengan mencapai nilai kerusakan 94\%. Hal itu diduga karena tidak diberikan perlakuan hujan sehingga herbisida meresap dengan baik pada gulma. Selain itu perlakuan B, C, D, dan E menunjukkan hasil yang baik, terlihat pada pengamatan 2 MSA dan 3 MSA yang mencapai nilai

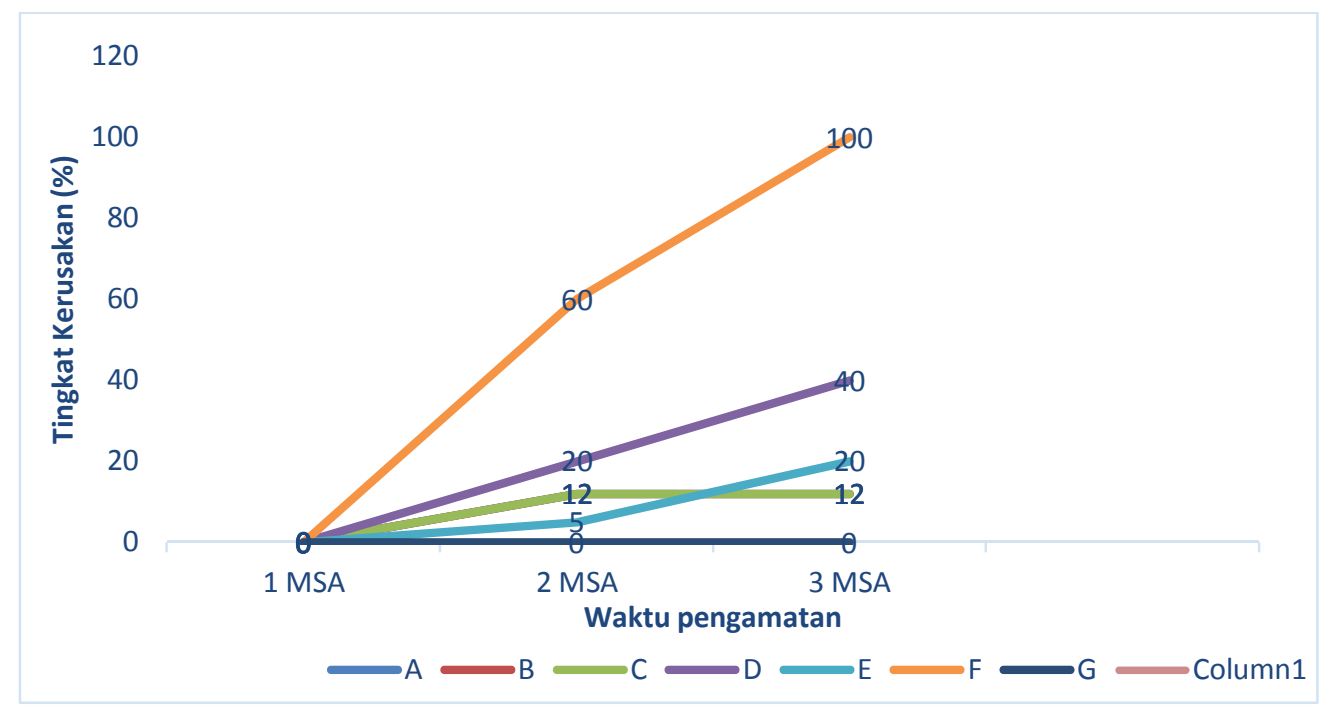

Gambar 1. Persentase Gejala Kerusakan Gulma Asystasia intrusa (\%) dalam 3 MSA.

Keterangan: - A: Kalium glifosat $660 \mathrm{~g} / \mathrm{L}+0$ jam diberikan hujan setelah aplikasi; - B: Kalium glifosat $660 \mathrm{~g} / \mathrm{L}+1$ jam diberikan hujan setelah aplikasi; - C: Kalium glifosat $660 \mathrm{~g} / \mathrm{L}+2$ jam diberikan hujan setelah aplikasi; - D: Kalium glifosat $660 \mathrm{~g} / \mathrm{L}+3$ jam diberikan hujan setelah aplikasi; - E: Kalium glifosat $660 \mathrm{~g} / \mathrm{L}+4$ jam diberikan hujan setelah aplikasi; - F: Kalium glifosat $660 \mathrm{~g} / \mathrm{L}$ tanpa hujan; - G: Tidak diberikan kalium glifosat $660 \mathrm{~g} / \mathrm{L}$

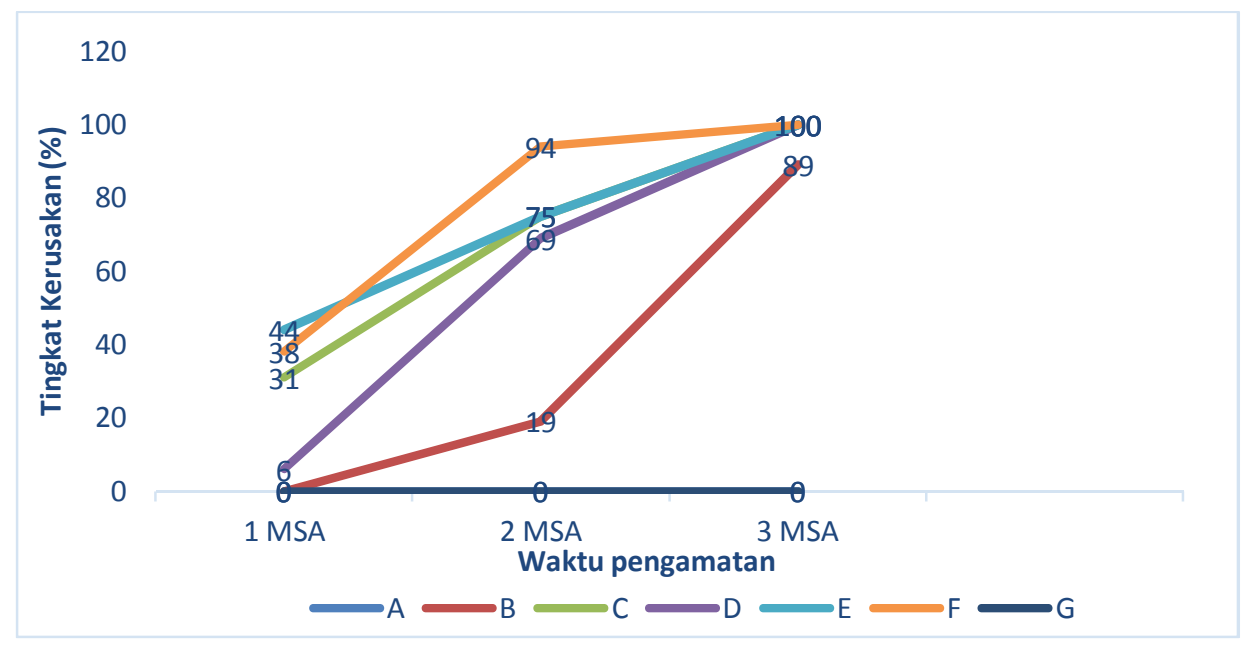

\section{Gambar 2. Persentase Gejala Kerusakan Gulma Imperata cylindrica (\%) dalam 3 MSA.}

Keterangan: - A: Kalium glifosat 660 g/L+ 0 jam diberikan hujan setelah aplikasi; - B: Kalium glifosat 660 g/L+ 1 jam diberikan hujan setelah aplikasi; - C: Kalium glifosat $660 \mathrm{~g} / \mathrm{L}+2$ jam diberikan hujan setelah aplikasi; - D: Kalium glifosat 660 g/L+ 3 jam diberikan hujan setelah aplikasi; - E: Kalium glifosat 660 g/L+ 4 jam diberikan hujan setelah aplikasi; - F: Kalium glifosat 660 g/L tanpa hujan; - G: Tidak diberikan kalium glifosat 660 g/L 
skoring $100 \%$ sedangkan perlakuan yang paling rendah hasilnya ditunjukan oleh perlakuan A dengan nilai $0 \%$ dari minggu pertama sampai minggu ketiga pengamatan. Perlakuan B, C, D, dan $E$ juga menunjukkan hasil yang baik, terlihat pada pengamatan 2 MSA dan 3 MSA yang mencapai nilai skoring $100 \%$. Penelitian lain menyebutkan bahwa gulma Imperata cylidrica efektif dikendalikan dengan menggunakan herbisida glifosat pada 3-4 MSA (Girsang, 2005). Sedangkan dalam penelitian ini pada 2 MSA Imperata cylindrica sudah dapat dikendalikan oleh herbisida kalium glifosat 660 $\mathrm{g} / \mathrm{L}$ dengan efektif. Hal ini sejalan dengan penelitian Mawandha $d k k$. (2018) bahwa pemberian herbisida glifosat akan efektif mengendalikan gulma Imperata cylindrica dalam kurun waktu 12 hari setelah aplikasi.

Hasil skoring gulma Borreria alata. Gulma Borreria alata merupakan gulma golongan daun lebar dan sering ditemukan hampir di semua daerah serta menjadi salah satu gulma utama di perkebunan kelapa sawit. Secara umum gulma ini dapat dikendalikan dengan baik melalui penggunaan herbisida kalium glifosat $660 \mathrm{~g} / \mathrm{L}$.

Hasil pengamatan pada Gambar 3 memperlihatkan bahwa perlakuan yang paling baik yaitu perlakuan $\mathrm{F}$ dalam mengendalikan gulma dengan nilai skoring $100 \%$ pada minggu ke 2 setelah aplikasi. Hal tersebut juga terjadi pada 6 jenis gulma lainnya. Sehingga dapat dipastikan herbisida kalium glifosat $660 \mathrm{~g} / \mathrm{L}$ efektif (cepat) mengendalikan gulma yang ada. Perlakuan lain juga menunjukkan nilai yang baik, terlihat pada perlakuan B, C, D, dan E yang terus meningkat dan mencapai tingkat keracunan $100 \%$ pada 3 MSA. Sedangkan perlakuan A menunjukkan nilai yang kurang baik dengan nilai $6 \%$ pada 2 MSA dan $25 \%$ pada 3 MSA. Hal ini sesuai dengan pendapat Wahyuningsih (2012) bahwa gulma Borreria alata mampu dikendalikan oleh herbisida glifosat dalam waktu 3 MSA.

Hasil skoring gulma Paspalum conjugatum. Pada Gambar 4 terlihat bahwa perlakuan $\mathrm{F}$ merupakan hasil terbaik dalam mengendalikan gulma. Perlakuan B memperlihatkan peningkatan yang cukup cepat dari pengamatan 2 MSA (31\%) ke pengamatan 3 MSA (100\%). Perlakuan C menunjukkan tingkat keracunan yang cukup tinggi sebesar $44 \%$ pada 2 MSA namun pada 3 MSA memperlihatkan yang relatif jauh dengan perlakua F. Hal ini berbeda dengan perlakuan $B$ yang meningkat lebih cepat padahal perlakuan B lebih cepat

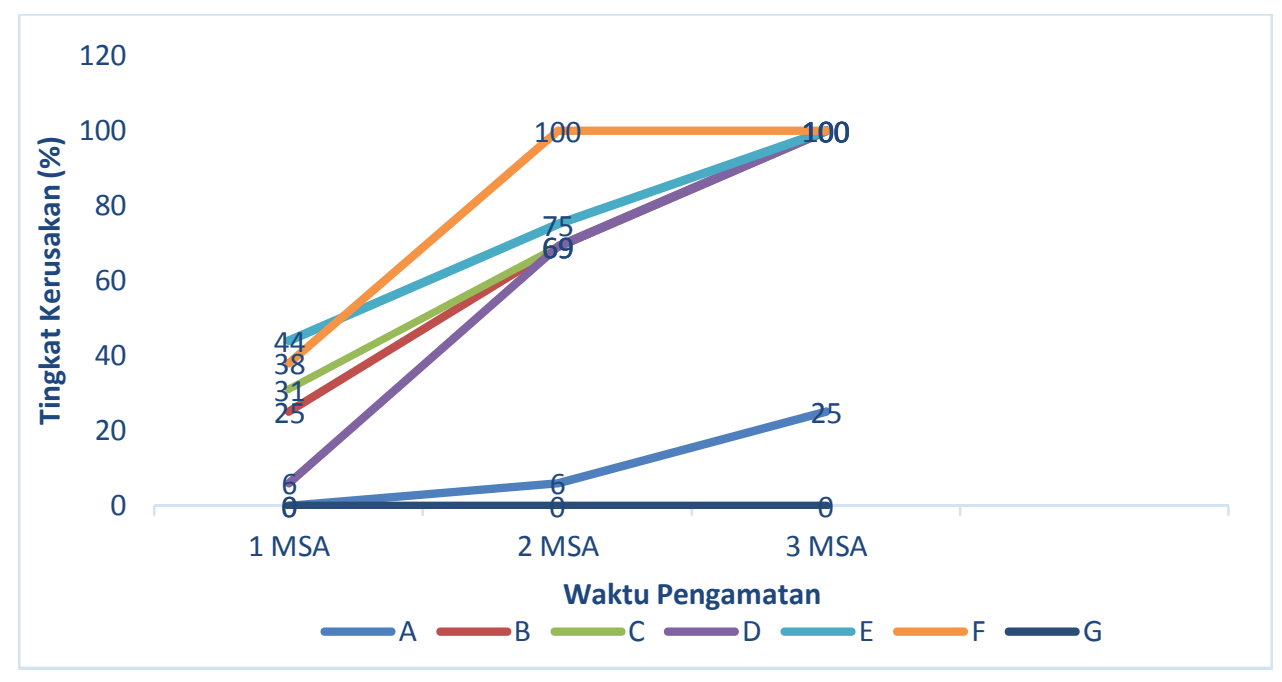

Gambar 3. Persentase Gejala Kerusakan Gulma Borreria alata (\%) dalam 3 MSA.

Keterangan: - A: Kalium glifosat 660 g/L+ 0 jam diberikan hujan setelah aplikasi; - B: Kalium glifosat 660 g/L+ 1 jam diberikan hujan setelah aplikasi; - C: Kalium glifosat $660 \mathrm{~g} / \mathrm{L}+2$ jam diberikan hujan setelah aplikasi; - D: Kalium glifosat $660 \mathrm{~g} / \mathrm{L}+3$ jam diberikan hujan setelah aplikasi; - E: Kalium glifosat $660 \mathrm{~g} / \mathrm{L}+4$ jam diberikan hujan setelah aplikasi; - F: Kalium glifosat $660 \mathrm{~g} / \mathrm{L}$ tanpa hujan; - G: Tidak diberikan kalium glifosat 660 g/L 


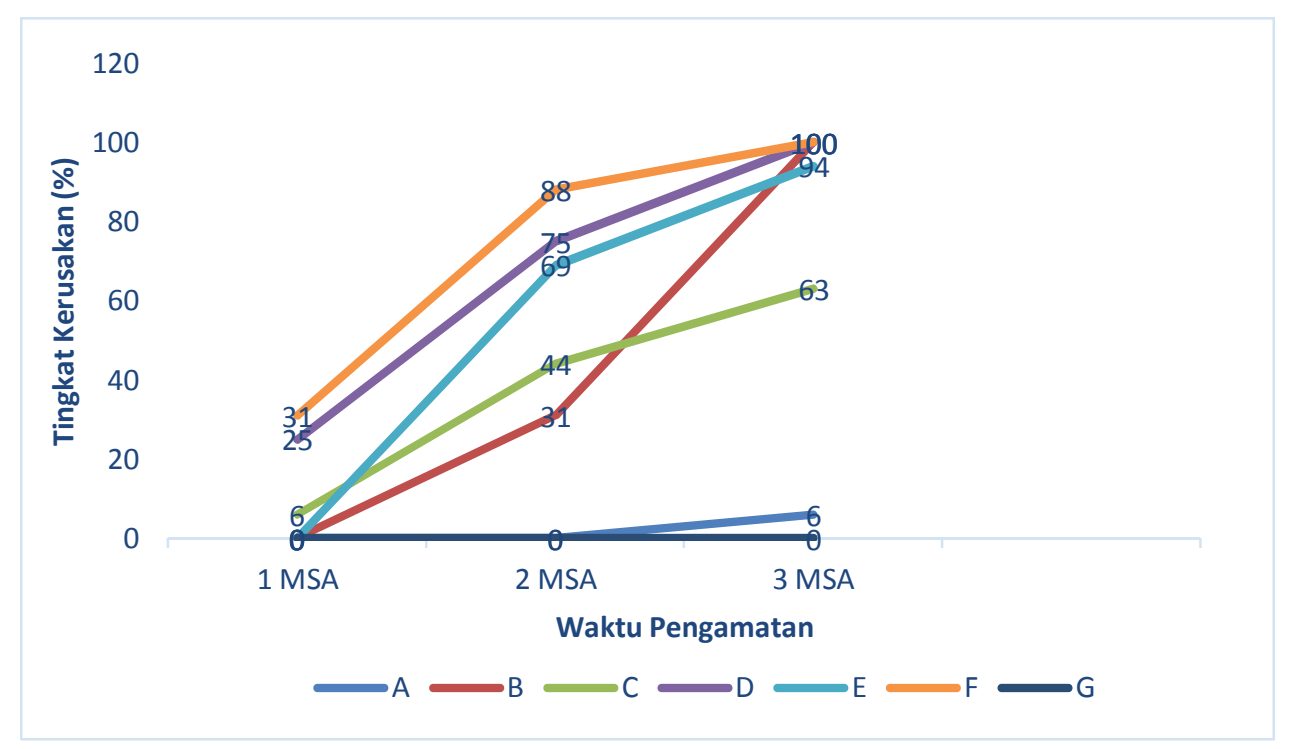

Gambar 4. Persentase Gejala Keracunan Gulma Paspalum conjugatum (\%) pada 3 MSA.

Keterangan: - A: Kalium glifosat 660 g/L+ 0 jam diberikan hujan setelah aplikasi; - B: Kalium glifosat 660 g/L+ 1 jam diberikan hujan setelah aplikasi; - C: Kalium glifosat $660 \mathrm{~g} / \mathrm{L}+2$ jam diberikan hujan setelah aplikasi; - D: Kalium glifosat 660 g/L+3 jam diberikan hujan setelah aplikasi; - E: Kalium glifosat 660 g/L+ 4 jam diberikan hujan setelah aplikasi; - F: Kalium glifosat 660 g/L tanpa hujan; - G: Tidak diberikan kalium glifosat 660 g/L

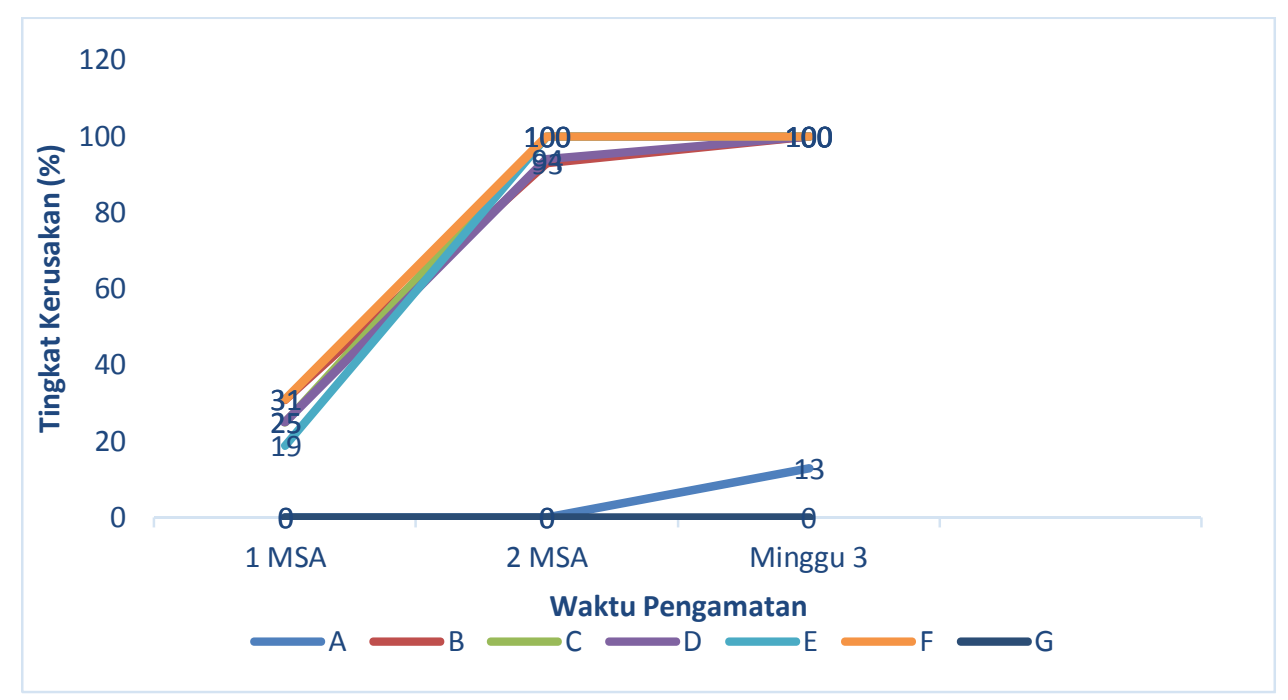

Gambar 5. Persentase Gejala Keracunan Gulma Ageratum conyzoides (\%) dalam 3 MSA.

Keterangan: - A: Kalium glifosat 660 g/L+ 0 jam diberikan hujan setelah aplikasi; - B: Kalium glifosat 660 g/L+ 1 jam diberikan hujan setelah aplikasi; - C: Kalium glifosat $660 \mathrm{~g} / \mathrm{L}+2$ jam diberikan hujan setelah aplikasi; - D: Kalium glifosat 660 g/L+3 jam diberikan hujan setelah aplikasi; - E: Kalium glifosat 660 g/L+ 4 jam diberikan hujan setelah aplikasi; - F: Kalium glifosat 660 g/L tanpa hujan; - G: Tidak diberikan kalium glifosat 660 g/L

diberikan perlakuan hujan dari pada perlakuan C. Diduga penyebaran herbisida peda perlakuan C tidak merata sehingga nilai kerusakan tidak mencapai $100 \%$ atau relatif jauh dengan perlakuan $F$ pada 3 MSA. Perlakuan D juga terlihat lebih baik dibanding perlakuan E meskipun pada 3 MSA tidak mendekati hasil perlakuan F. Perlakuan A menunjukkan hasil yang kurang baik.
Menurut Reddy (2000) gulma Paspalum conjugatum membutuhkan waktu selama 6 MSA untuk dapat dikendalikan oleh herbisida Isopropanil glifosat. Hal tersebut menunjukkan hasil yang lebih baik diperlihatkan oleh herbisida kalium glifosat $660 \mathrm{~g} / \mathrm{L}$, karena membutuhkan waktu yang lebih singkat dalam mengendalikan gulma Paspalum conjugatum yaitu 3 MSA. 
Hasil skoring gulma Ageratum conyzoides. Pada Gambar 5 menunjukkan bahwa hampir semua perlakuan mampu mengendalikan gulma Ageratum conizoides sejak 2 MSA dengan nilai persentase kerusakan 93$100 \%$, kecuali perlakuan A. Perlakuan A memperlihatkan hasil yang kurang baik yaitu hanya mencapai $13 \%$ pada 3 MSA. Hal ini sesuai dengan pendapat Sembodo (2010) bahwa gulma Ageratum conizoides merupakan gulma yang tidak sulit untuk dikendalikan, maka hal ini terlihat bahwa pengendalian hanya membutuhkan waktu 2 minggu setelah aplikasi.

Hasil skoring gulma Setaria plicata. Gambar 6 menunjukkan bahwa perlakuan C, D, $\mathrm{E}$, dan $\mathrm{F}$ menunjukkan hasil yang baik, terlihat pada 2 MSA telah mencapai nilai $94-100 \%$. Perlakuan B hanya mencapai nilai kerusakan $50 \%$ pada 2 MSA dan 69\% pada 3 MSA, sedangkan perlakuan A menunjukkan nilai yang rendah sebesar $31 \%$ pada 3 MSA. Gulma Setaria plicata membutuhkan waktu 4 MSA untuk dikendalikan secara optimal (Girsang, 2005), sehingga dapat dikatakan bahwa herbisida kalium glifosat $660 \mathrm{~g} / \mathrm{L}$ lebih efektif jika ditinjau dari waktu pengendaliannya.

Bobot kering dan kerusakan gulma Asystasia intrusa. Gulma Asystasia intrusa merupakan gulma utama dalam perkebunan kelapa sawit. Gulma ini memliki pertumbuhan yang cepat dan tergolong sulit dikendalikan oleh beberapa herbisida. Herbisida kalium glifosat $660 \mathrm{~g} / \mathrm{L}$ menunjukan hasil yang kurang baik dalam mengendalikan gulma Asystasia intrusa, yang ditunjukan pada Tabel 1.

Tabel 1. Rata-rata Bobot Kering dan Persentase Kerusakan Gulma Asystasia intrusa.

\begin{tabular}{ccc}
\hline \multirow{2}{*}{ Perlakuan } & \multicolumn{2}{c}{ Rata-rata } \\
\cline { 2 - 3 } & Bobot kering & Kerusakan (\%) \\
\hline $\mathrm{A}$ & $2,65 \mathrm{a}$ & $1,90 \mathrm{a}$ \\
$\mathrm{B}$ & $2,35 \mathrm{ab}$ & $12,5 \mathrm{ab}$ \\
$\mathrm{C}$ & $2,20 \mathrm{abc}$ & $17,9 \mathrm{abc}$ \\
$\mathrm{D}$ & $1,53 \mathrm{bc}$ & $44,2 \mathrm{bc}$ \\
$\mathrm{E}$ & $1,23 \mathrm{c}$ & $54,1 \mathrm{c}$ \\
$\mathrm{F}$ & $0,00 \mathrm{~d}$ & $100 \mathrm{~d}$ \\
$\mathrm{G}$ & $2,70 \mathrm{a}$ & $0,00 \mathrm{a}$ \\
\hline
\end{tabular}

Keterangan: Nilai yang diikuti huruf yang berbeda dinyatakan perlakuan tersebut berbeda nyata menurut uji Duncan pada taraf $5 \%$.

Keterangan: - A: Kalium glifosat 660 g/L+ 0 jam diberikan hujan setelah aplikasi; - B: Kalium glifosat $660 \mathrm{~g} / \mathrm{L}+1$ jam diberikan hujan setelah aplikasi; - C: Kalium glifosat $660 \mathrm{~g} / \mathrm{L}+2$ jam diberikan hujan setelah aplikasi; - D: Kalium glifosat $660 \mathrm{~g} / \mathrm{L}+3 \mathrm{jam}$ diberikan hujan setelah aplikasi; - E: Kalium glifosat $660 \mathrm{~g} / \mathrm{L}+4$ jam diberikan hujan setelah aplikasi; - F: Kalium glifosat $660 \mathrm{~g} / \mathrm{L}$ tanpa hujan; - G: Tidak diberikan kalium glifosat $660 \mathrm{~g} / \mathrm{L}$

Berdasarkan data yang disajikan pada Tabel 2. Bobot kering gulma Asystasia intrusa masih memiliki bobot kering yang tidak jauh

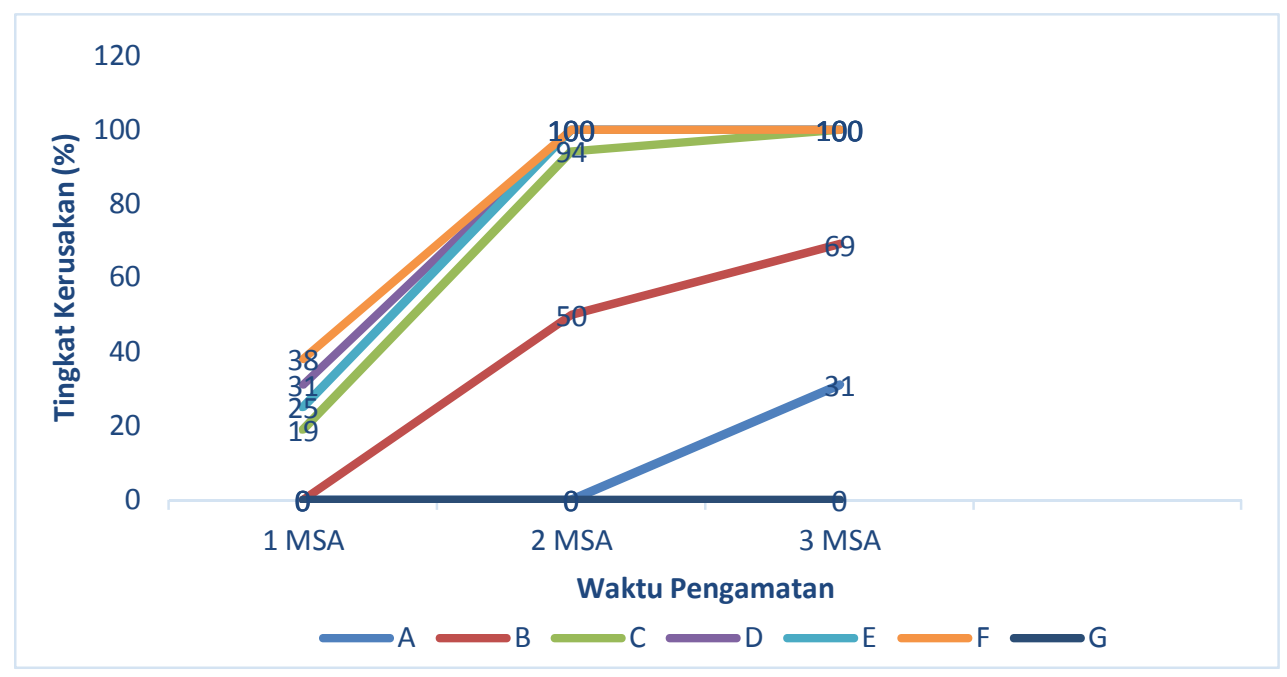

Gambar 6. Persentase Gejala Keracunan Gulma Setaria plicata (\%) dalam 3 MSA.

Keterangan: - A: Kalium glifosat 660 g/L+ 0 jam diberikan hujan setelah aplikasi; - B: Kalium glifosat 660 g/L+ 1 jam diberikan hujan setelah aplikasi; - C: Kalium glifosat $660 \mathrm{~g} / \mathrm{L}+2$ jam diberikan hujan setelah aplikasi; - D: Kalium glifosat 660 g/L+3 jam diberikan hujan setelah aplikasi; - E: Kalium glifosat $660 \mathrm{~g} / \mathrm{L}+4$ jam diberikan hujan setelah aplikasi; - F: Kalium glifosat $660 \mathrm{~g} / \mathrm{L}$ tanpa hujan; - G: Tidak diberikan kalium glifosat $660 \mathrm{~g} / \mathrm{L}$ 
berbeda dengan kontrol pada perlakuan A - E sehingga persentase kerusakannya pun tidak sebesar perlakuan F yang mencapai $100 \%$. Hal tersebut menunjukkan gulma Asystasia intrusa membutuhkan waktu lebih lama untuk dikendalikan oleh herbisida kalium glifosat $660 \mathrm{~g} / \mathrm{L}$. Nilai persentase yang paling mendekati perlakuan $\mathrm{F}$ adalah perlakuan $\mathrm{E}$ sebesar $54.1 \%$, namun persentasenya relatif jauh, sehingga dapat dikatakan bahwa herbisida kalium glifosat sangat dipengaruhi oleh turun hujan dalam pengendalian gulma Asystasia intrusa. Selain itu juga, herbisida kalium glifosat $660 \mathrm{~g} / \mathrm{L}$ membutuhkan waktu lebih dari 4 jam untuk meresap pada gulma $A$. intrusa agar dapat mencapai nilai hasil kerusakan 100\%. Menurut Sriyani (2010) gulma A.intrusa cukup sulit dikendalikan oleh beberapa herbisida, karena diduga lapisan kutikula pada daun sulit ditembus. Sedangkan menurut Priambodo (2017) herbisida kalium glifosat yang dihujani $0-4$ jam setelah aplikasi tidak efektif mengendalikan pertumbuhan gulma Asystasia intrusa.

Tabel 2. Rata-rata Bobot Kering dan Persentase Kerusakan Gulma Imperata cylindrica.

\begin{tabular}{ccc}
\hline \multirow{2}{*}{ Perlakuan } & \multicolumn{2}{c}{ Rata-rata } \\
\cline { 2 - 3 } & Bobot kering & Kerusakan (\%) \\
\hline A & $2,575 \mathrm{a}$ & $16,0 \mathrm{a}$ \\
$\mathrm{B}$ & $0,625 \mathrm{~b}$ & $79,6 \mathrm{~b}$ \\
$\mathrm{C}$ & $0,000 \mathrm{c}$ & $100 \mathrm{c}$ \\
$\mathrm{D}$ & $0,000 \mathrm{c}$ & $100 \mathrm{c}$ \\
$\mathrm{E}$ & $0,000 \mathrm{c}$ & $100 \mathrm{c}$ \\
F & $0,000 \mathrm{c}$ & $100 \mathrm{c}$ \\
G & $3,075 \mathrm{a}$ & $0,00 \mathrm{a}$ \\
\hline
\end{tabular}

Keterangan: Nilai yang diikuti huruf yang berbeda dinyatakan perlakuan tersebut berbeda nyata menurut uji Duncan pada taraf $5 \%$.

Keterangan: - A: Kalium glifosat 660 g/L+ 0 jam diberikan hujan setelah aplikasi; - B: Kalium glifosat $660 \mathrm{~g} / \mathrm{L}+1$ jam diberikan hujan setelah aplikasi; - C: Kalium glifosat $660 \mathrm{~g} / \mathrm{L}+2$ jam diberikan hujan setelah aplikasi; - D: Kalium glifosat 660 g/L+ 3 jam diberikan hujan setelah aplikasi; - E: Kalium glifosat $660 \mathrm{~g} / \mathrm{L}+4$ jam diberikan hujan setelah aplikasi; - F: Kalium glifosat 660 g/L tanpa hujan; - G: Tidak diberikan kalium glifosat $660 \mathrm{~g} / \mathrm{L}$

Bobot kering dan persentase kerusakan gulma Imperata cylindrica. Herbisida kalium glifosat menunjukkan hasil yang baik dalam mengendalikan gulma Imperata cylindrica, yang ditunjukan pada Tabel 2. Berdasarkan data pada Tabel 2 menunjukkan bahwa perlakuan C - F adalah hasil yang terbaik, terlihat pada bobot kering gulma dengan nilai $0 \mathrm{~g}$ (gulma mati) sehingga persentase kerusakan sebesar $100 \%$. Perlakuan B menunjukkan hasil yang cukup baik jika dibandingkan dengan perlakuan $\mathrm{A}$, dengan bobot kering sebesar $0,625 \mathrm{~g}$ dan persentase kerusakan sebesar $79,6 \%$. Hal ini menunjukkan bahwa aplikasi herbisida kalium glifosat $660 \mathrm{~g} / \mathrm{L}$ tidak dipengaruhi oleh hujan dalam waktu 2 jam setelah aplikasi, bahkan 1 jam pun masih memperlihatkan nilai persentase yang cukup baik $(79,6 \%)$. Menurut Girsang (2005) herbisida glifosat tidak terpengaruhi efektifitasnya oleh pencucian air hujan dalam selang waktu 2 jam setelah aplikasi.

Bobot kering dan persentase kerusakan gulma Borreria alata. Berdasarkan data yang disajikan pada Tabel 3 menunjukkan hasil terbaik untuk perlakuan B - F terlihat pada bobot kering dengan nilai 0 untuk perlakuan $\mathrm{B}$, D, E, dan F, serta 0,2 g untuk perlakuan C, sehingga persentase kerusakanyapun secara berurutan sbesar $100 \%$. 90, 100\%, $100 \%$, dan $100 \%$. Perlakuan A menunjukkan hasil kurang baik terlihat dari bobot kering sebesar 2,08 $\mathrm{g}$ mendekati kontrol sehingga persentase kerusakan hanya mencapai 9\%. Menurut Sriyani (2010) herbisida secara umum diabsorpsi oleh tumbuhan (gulma) membutuhkan waktu lebih dari 2 jam. Hal itu menunjukkan bahwa herbisida kalium glifosat $660 \mathrm{~g} / \mathrm{L}$ dalam waktu 1 jam cepat diabsorpsi oleh gulma dalam mengendalikan gulma Borreria alata.

Tabel 3. Rata-rata Bobot Kering dan Persentase Kerusakan Gulma Borreria alata.

\begin{tabular}{ccc}
\hline \multirow{2}{*}{ Perlakuan } & \multicolumn{2}{c}{ Rata-rata } \\
\cline { 2 - 3 } & Bobot kering & Kerusakan (\%) \\
\hline A & $2,08 \mathrm{a}$ & $9,00 \mathrm{a}$ \\
$\mathrm{B}$ & $0,00 \mathrm{~b}$ & $100 \mathrm{~b}$ \\
$\mathrm{C}$ & $0,20 \mathrm{~b}$ & $90,0 \mathrm{~b}$ \\
$\mathrm{D}$ & $0,00 \mathrm{~b}$ & $100 \mathrm{~b}$ \\
$\mathrm{E}$ & $0,00 \mathrm{~b}$ & $100 \mathrm{~b}$ \\
F & $0,00 \mathrm{~b}$ & $100 \mathrm{~b}$ \\
G & $2,28 \mathrm{a}$ & $0,00 \mathrm{a}$ \\
\hline
\end{tabular}

Keterangan: Nilai yang diikuti huruf yang berbeda dinyatakan perlakuan tersebut berbeda nyata menurut uji Duncan pada taraf $5 \%$.

Keterangan: - A: Kalium glifosat $660 \mathrm{~g} / \mathrm{L}+0$ jam diberikan hujan setelah aplikasi; - B: Kalium glifosat $660 \mathrm{~g} / \mathrm{L}+1$ jam diberikan hujan setelah aplikasi; - C: Kalium glifosat $660 \mathrm{~g} / \mathrm{L}+2$ jam diberikan hujan setelah aplikasi; - D: Kalium glifosat $660 \mathrm{~g} / \mathrm{L}+3 \mathrm{jam}$ diberikan hujan setelah aplikasi; - E: Kalium glifosat $660 \mathrm{~g} / \mathrm{L}+4$ jam diberikan hujan setelah aplikasi; - F: Kalium glifosat $660 \mathrm{~g} / \mathrm{L}$ tanpa hujan; - G: Tidak diberikan kalium glifosat $660 \mathrm{~g} / \mathrm{L}$ 
Bobot kering persentase kerusakan gulma Paspalum conjugatum. Berdasarkan data pada Tabel 4 pemberian herbisida kalium glifosat menunjukan hasil yang baik dalam mengendalikan gulma Paspalum conjugatum.

Tabel 4. Rata-rata Bobot Kering dan Persentase Kerusakan Gulma Paspalum conjugatum.

\begin{tabular}{ccc}
\hline \multirow{2}{*}{ Perlakuan } & \multicolumn{2}{c}{ Rata-rata } \\
\cline { 2 - 3 } & Bobot kering & Kerusakan (\%) \\
\hline $\mathrm{A}$ & $2,00 \mathrm{a}$ & $17,9 \mathrm{a}$ \\
$\mathrm{B}$ & $1,80 \mathrm{a}$ & $26,3 \mathrm{a}$ \\
$\mathrm{C}$ & $1,10 \mathrm{ab}$ & $51,5 \mathrm{ab}$ \\
$\mathrm{D}$ & $0,00 \mathrm{c}$ & $100 \mathrm{c}$ \\
$\mathrm{E}$ & $0,40 \mathrm{bc}$ & $85,1 \mathrm{bc}$ \\
$\mathrm{F}$ & $0,00 \mathrm{c}$ & $100 \mathrm{c}$ \\
$\mathrm{G}$ & $2,40 \mathrm{a}$ & $0,00 \mathrm{a}$ \\
\hline
\end{tabular}

Keterangan: Nilai yang diikuti huruf yang berbeda dinyatakan perlakuan tersebut berbeda nyata menurut uji Duncan pada taraf $5 \%$.

Keterangan: - A: Kalium glifosat $660 \mathrm{~g} / \mathrm{L}+0$ jam diberikan hujan setelah aplikasi; - B: Kalium glifosat $660 \mathrm{~g} / \mathrm{L}+1$ jam diberikan hujan setelah aplikasi; - C: Kalium glifosat $660 \mathrm{~g} / \mathrm{L}+2$ jam diberikan hujan setelah aplikasi; - D: Kalium glifosat $660 \mathrm{~g} / \mathrm{L}+3 \mathrm{jam}$ diberikan hujan setelah aplikasi; - E: Kalium glifosat $660 \mathrm{~g} / \mathrm{L}+4$ jam diberikan hujan setelah aplikasi; - F: Kalium glifosat $660 \mathrm{~g} / \mathrm{L}$ tanpa hujan; - G: Tidak diberikan kalium glifosat $660 \mathrm{~g} / \mathrm{L}$

Tabel 5. Rata-rata Bobot Kering dan Persentase Kerusakan Gulma Ageratum conyzoides.

\begin{tabular}{ccc}
\hline \multirow{2}{*}{ Perlakuan } & \multicolumn{2}{c}{ Rata-rata } \\
\cline { 2 - 3 } & Bobot kering & Kerusakan (\%) \\
\hline $\mathrm{A}$ & $0,52 \mathrm{a}$ & $17,9 \mathrm{a}$ \\
$\mathrm{B}$ & $0,00 \mathrm{~b}$ & $100 \mathrm{~b}$ \\
$\mathrm{C}$ & $0,00 \mathrm{~b}$ & $100 \mathrm{~b}$ \\
$\mathrm{D}$ & $0,00 \mathrm{~b}$ & $100 \mathrm{~b}$ \\
$\mathrm{E}$ & $0,00 \mathrm{~b}$ & $100 \mathrm{~b}$ \\
$\mathrm{~F}$ & $0,00 \mathrm{~b}$ & $100 \mathrm{~b}$ \\
$\mathrm{G}$ & $0,65 \mathrm{a}$ & $0,00 \mathrm{a}$ \\
\hline
\end{tabular}

Keterangan: Nilai yang diikuti huruf yang berbeda dinyatakan perlakuan tersebut berbeda nyata menurut uji Duncan pada taraf $5 \%$.

Keterangan: - A: Kalium glifosat 660 g/L+ 0 jam diberikan hujan setelah aplikasi; - B: Kalium glifosat $660 \mathrm{~g} / \mathrm{L}+1$ jam diberikan hujan setelah aplikasi; - C: Kalium glifosat $660 \mathrm{~g} / \mathrm{L}+2$ jam diberikan hujan setelah aplikasi; - D: Kalium glifosat $660 \mathrm{~g} / \mathrm{L}+3 \mathrm{jam}$ diberikan hujan setelah aplikasi; - E: Kalium glifosat $660 \mathrm{~g} / \mathrm{L}+4$ jam diberikan hujan setelah aplikasi; - F: Kalium glifosat $660 \mathrm{~g} / \mathrm{L}$ tanpa hujan; - G: Tidak diberikan kalium glifosat $660 \mathrm{~g} / \mathrm{L}$
Berdasarkan data yang disajikan pada Tabel 4 menunjukkan bahwa perlakuan yang terbaik adalah $\mathrm{C}$ dan $\mathrm{F}$ dengan bobot kering 0 dan persentase kerusakan 100\%. Perlakuan E menunjukkan hasil yang cukup baik karena memiliki bobot kering sebesar 0,4 $\mathrm{g}$ dan persentase kerusakan $85,1 \%$. Perlakuan C menunjukkan bobot kering gulma yang cukup besar yaitu 1,1 g dengan persentase kerusakan 51,5\%. Perlakuan A dan B menunjukkan hasil yang kurang yaitu hanya mencapai $17,9 \%$ dan $26,3 \%$ untuk persentase kerusakannya. Hal ini menunjukkan bahwa herbisida kalium glifosat $660 \mathrm{~g} / \mathrm{L}$ dipengaruhi oleh pencucian air hujan pada selang waktu 2 jam setelah aplikasi. Sejalan dengan penelitian Girsang (2005) bahwa pemberian herbisida glifosat tidak akan efektif mengendalikan gulma tertentu bila dalam selang waktu 2 jam terkena pencucian oleh air hujan.

Tabel 6. Rata-rata Bobot Kering dan Persentase Kerusakan Gulma Setaria plicata.

\begin{tabular}{ccc}
\hline \multirow{2}{*}{ Perlakuan } & \multicolumn{2}{c}{ Rata-rata } \\
\cline { 2 - 3 } & Bobot kering & Kerusakan (\%) \\
\hline A & $2,475 \mathrm{a}$ & $10,8 \mathrm{a}$ \\
$\mathrm{B}$ & $2,025 \mathrm{~b}$ & $27,5 \mathrm{a}$ \\
$\mathrm{C}$ & $0,00 \mathrm{~b}$ & $100 \mathrm{~b}$ \\
$\mathrm{D}$ & $0,00 \mathrm{~b}$ & $100 \mathrm{~b}$ \\
E & $0,00 \mathrm{~b}$ & $100 \mathrm{~b}$ \\
F & $0,00 \mathrm{~b}$ & $100 \mathrm{~b}$ \\
G & $2,775 \mathrm{a}$ & $0,00 \mathrm{a}$ \\
\hline
\end{tabular}

Keterangan: Nilai yang diikuti huruf yang berbeda dinyatakan perlakuan tersebut berbeda nyata menurut uji Duncan pada taraf $5 \%$.

Keterangan: - A: Kalium glifosat 660 g/L+ 0 jam diberikan hujan setelah aplikasi; - B: Kalium glifosat $660 \mathrm{~g} / \mathrm{L}+1$ jam diberikan hujan setelah aplikasi; - C: Kalium glifosat $660 \mathrm{~g} / \mathrm{L}+2$ jam diberikan hujan setelah aplikasi; - D: Kalium glifosat $660 \mathrm{~g} / \mathrm{L}+3$ jam diberikan hujan setelah aplikasi; - E: Kalium glifosat $660 \mathrm{~g} / \mathrm{L}+4$ jam diberikan hujan setelah aplikasi; - F: Kalium glifosat 660 g/L tanpa hujan; - G: Tidak diberikan kalium glifosat $660 \mathrm{~g} / \mathrm{L}$

Bobot kering persentase kerusakan gulma Ageratum conyzoides. Berdasarkan data yang disajikan pada Tabel 5 menunjukkan hasil yang paling baik terlihat pada perlakuan B - F dengan bobot kering $0 \mathrm{~g}$ dan persentase kerusakan mencapai $100 \%$. Sedangkan perlakuan A menunjukkan hasil yang kurang baik yang hanya mencapai $17.9 \%$. Menurut Sriyani (2010) herbisida secara umum diabsorpsi oleh gulma membutuhkan waktu lebih dari 2 jam. Menurut Girsang (2005) herbisida glifosat tidak 
terpengaruhi oleh pencucian air hujan dalam selang waktu 2 jam setelah aplikasi. Hal ini diduga herbisida kalium glifosat $660 \mathrm{~g} / \mathrm{L}$ memiliki formulasi yang berbeda sehingga lebih baik dalam mengendalikan gulma Ageratum conyzoides.

Bobot kering persentase kerusakan gulma Setaria plicata. Tabel 6 menunjukkan bahwa hasil yang paling baik terdapat pada perlakuan $\mathrm{C}-\mathrm{F}$ dengan bobot kering $0 \mathrm{~g}$ dan persentase kerusakan mencapai $100 \%$. Perlakuan A dan B memperlihatkan hasil yang kurang baik yaitu memiliki bobot kering yang tidak jauh berbeda dengan kontrol sehingga kerusakannya hanya mencapai $10.8 \%$ dan 27.5\%. Menurut Sriyani (2010) herbisida secara umum diabsorpsi oleh gulma membutuhkan waktu lebih dari 2 jam.

\section{Kesimpulan dan Saran}

1. Herbisida kalium glifosat $660 \mathrm{~g} / \mathrm{L}$ mampu mengendalikan 5 jenis gulma yaitu Imperata cylindrica (persentase kerusakan 100\%), Borreria alata (persentase kerusakan 90100\%), Paspalum conjugatum (persentase kerusakan 51,5-100\%), Ageratum conyzoides (persentase kerusakan 100\%), dan Setaria plicata (persentase kerusakan 100\%) secara efektif walaupun tercuci air hujan antara 2 4 jam setelah aplikasi.

2. Herbisida kalium glifosat $660 \mathrm{~g} / \mathrm{L}$ mampu mengendalikan gulma Imperata cylindrical (persentase kerusakan 79,6\%),, Borreria alata (persentase kerusakan 100\%), dan Ageratum cinyzoides (persentase kerusakan 100\%), dengan persentase rentang waktu kurang dari 2 jam setelah aplikasi sebelum tercuci air hujan.

\section{Daftar Pustaka}

Astuti, M., Hafiza, E. Yuningsih, I. M. Nasution, D. Mustikawati, dan A. R. Wasingun. 2014. Budidaya Kelapa Sawit. Direktorat Jenderal Perkebunan Kementerian Pertanian R. I., Jakarta.

Girsang, W. 2005. Pengaruh Tingkat Dosis Herbisida Isopropilamina glifosat dan selang waktu terjadinya pencucian setelah aplikasi terhadap efektivitas pengendalian gulma perkebunan karet (Hevea brassiliensis) TBM. Jurnal Penelitian Bidang Ilmu Pertanian, 3(2):31-36Mawandha, H. G., A.T. Soejono, dan Fiona Alfani. 2018. Pengaruh Dosis Herbisida Glifosat Terhadap Beberapa Jenis Gulma Utama Perkebunan Kelapa Sawit. Agroista Jurnal Agroteknologi, 2 (1) : 83 - 92.

Pokja Sawit. 2008. Pengelolaan Perkebunan Sawit Berkelanjutan. Pemerintah Provinsi Kalimantan Tengah, Palangkaraya.

Priambodo, I. B. 2017. Efikasi Herbisida Kalium Glifosat Terhadap Waktu Turun Hujan Setelah Aplikasi Pada Pengendalian Beberapa Spesies Gulma. Fak. Pertanian Univ. Lampung, Bandar Lampung.

Purwasih, Suhenny D. Sabrino, dan Rahmidiyani. 2013. Struktur Gulma pada tegakan di lahan gambut (studi kasus pada HPHTI PT Arara Abadi, Riau). Balai Penelitian Hutan Pengahasil Serat, 4 (1). Hal 33-40.

Reddy, K.N. 2000. Factors Affecting Toxicity, Absorption, and Translocation of Glyphosate in Redvine (Brunnichia ovata). J. Weed Technology, 14: 457 - 462.

Reddy, K.N., dan M. Singh. 1992. Organosilicone Adjuvant Effects onGlyphosate Efficacy and Rainfastness. J. Weed Technology, 6: 361-365.

Risza, S. 1994. Kelapa Sawit Upaya Peningkatan Produksi. Kanisius. Yogyakarta. $181 \mathrm{hlm}$.

Sembodo, D. 2010. Gulma dan pengelolaannya. Graha Ilmu. Yogyakarta.

Sriyani, N. 2010. Pengelolaan Gulma dan Herbisida untuk Meningkatkan Produktivitas Lahan Pertanian Secara Berkelanjutan. Pidato Ilmiah Pengukuhan Guru Besar Bidang Pengelolaan Gulma dan Herbisida. Fak. Pertanian, Univ. Lampung.

Supriadi, A., S. Tjokrowardojo, E. Djauhariya. dan S. Rahayuningsih. 2012. Pengembangan Formulasi Herbisida Berbasis Asam Asetat Untuk Mengendalikan Gulma Pada Tanaman Kelapa Sawit. Laporan Hasil Riset Balai Penelitian Tanaman Rempah Dan Obat. Bogor

Wahyuningsih P. A., T. Widiharih, H. Yasin. 2012. Optimasi Waktu Efektif Aplikasi Herbisida Pada Tanaman Kelapa Sawit (Elaeis Guineensis Jacq.) Dengan Fungsi Estimasi Densitas Kernel. Universitas Diponegoro 